\title{
Adult B Acute Lymphoblastic Leukemia with $\mathrm{t}(9 ; 22)(\mathrm{q} 34.1 ; \mathrm{q11.2}) ; \mathrm{BCR}-\mathrm{ABL} 1$
}

National Cancer Institute

\section{Source}

National Cancer Institute. Adult B Acute Lymphoblastic Leukemia with t(9;22)

(q34.1:q11.2): BCR-ABL1. NCI Thesaurus. Code C114819.

A B-cell acute leukemia that occurs during adulthood. It is characterized by the presence

of lymphoblasts that carry a translocation between the BCR gene on chromosome 22

and the ABL1 gene on chromosome 9. It results in the production of the p190 kd or p210

$\mathrm{kd}$ fusion protein. It has an unfavorable clinical outcome. 